\title{
Organic Cationic Drugs and Renal Creatinine Secretion
}

\begin{tabular}{|l|l|}
\hline H.G. & Harry G. \\
\hline $\begin{array}{l}\text { Harry G. Preuss, MD, Professor of Medicine and Pathology, } 153 \text { Basis Science Building, } 4000 \text { Reservoir Road N.W., } \\
\text { Washington DC 20007 (USA) }\end{array}$
\end{tabular}

Sir,

Regarding the article 'Inhibition of renal creatinine secretion by cimetidine in humans' by Burgess et al. -Renal Physiol., Basel 5: 27-30 (1982) -, this is not the first cationic drug to show substantial inhibition of tubular secretion of creatinine in humans as stated in the article. In 1975, Berglundet al. [1] showed elevated serum creatinine concentrations, approximately 25\%, after 5 days of trimethoprim, $160 \mathrm{mg}$ twice daily. The average increase of $2 \mathrm{mg} / \mathrm{dl}$ creatinine was reversible. 131I-iothalamate clearances were unchanged even though clearances of creatinine decreased significantly. From the results, Berglund and his co-authors hypothesized that trimethoprim competitively inhibits the tubular secretion of creatinine through the organic cation (base) secretory mechanism.

Creatinine is filtered, reabsorbed, and secreted by kidneys [2] and seems to be secreted by both organic anion and organic cation transport in some species [3, 4]. Using in vitro techniques, Lee et-al. [5] showed that trimethoprim inhibits active uptake of 14C-TEA (organic cation), not its efflux, and that the inhibition is competitive. Thus, the ability of trimethoprim to compete for organic cation transport was established. These results are consistent with the hypothesis of Berglund et al. [1] concerning the inhibition of renal creatinine secretion via competition for transport.

Therefore, both trimethoprim and cimetidine, two drugs used heavily in clinical practice, may elevate serum creatinine concentrations without causing renal malfunction. Accordingly, other cationic drugs might be expected to cause similar findings. The knowledge that organic cations can elevate serum creatinine without influencing the glomerular filtration rate is important to clinicians, for continuance of a successful therapeutic regimen may depend on it.

References

Berglund, F.; Killander, J.: Pompeius, R.: Effect of trimethoprimsulfamethoxazole on the renal excretion of creatinine in man. J. Urol. 114: 802-808 (1975).

Berglund, F.: Urinary excretion patterns for substances with simultaneous secretion and reabsorp-tion by active transport. Acta physiol. scand. 52: 276-290 (1961).

O’Connell, J.M.B.; Romeo, J.A.; Mudge, G.: Renal tubular secretion of creatinine in the dog. Am. J. Physiol. 203: 985-990 (1962).

Arendshorst, W.J.; Selkurt, E. E.: Renal tubular mechanisms for creatinine secretion in the guinea pig. Am. J. Physiol. 218:1161-1669 (1970).

Lee, J.; Hollyer, R.; Rodelas, R.; Preuss, H. G.: The influence of trimethoprim, sulfamethoxazole and creatinine on renal organic anion and cation transport in rat kidney tissue. Toxicol. appl. Pharmacol. 58:184-193 (1981). 